\title{
Utilizing Slurry and Carwash Wastewater as Fresh Water Replacement in Concrete Properties
}

\author{
Shahiron Shahidan ${ }^{1, *}$, Aeslina Abdul Kadir ${ }^{2}$, Lau Hai Yee ${ }^{3}$, Nurul Izzati Raihan Ramzi ${ }^{4}$, \\ and Faisal Sheikh ${ }^{5}$ \\ 1,3,4,5 Jamilus Research Centre, Faculty of Civil and Environmental Engineering, Universiti Tun \\ Hussein Onn Malaysia \\ ${ }^{2}$ Department of Water and Environmental Engineering, Faculty of Civil and Environmental \\ Engineering, Universiti Tun Hussein Onn Malaysia
}

\begin{abstract}
The high demand for concrete production generates wastewater which causes environmental problems. However, if wastewater is able to be recycled as part of engineering construction materials, many benefits can be reaped. Unfortunately, the use of wastewater in manufacturing concrete is not common. Therefore, this research aims to identify the influence of using slurry water and car wash wastewater on concrete properties, focusing particularly on its mechanical properties. The basic characteristics of wastewater were studied according to USEPA method while the properties of concrete with wastewater were compared according to ASTM C1602 and BS EN 1008 standards. In this paper, the compressive strength, modulus of elasticity and tensile strength were examined in order to determine the mechanical properties of concrete. The wastewater was replaced in the concrete mix from $0 \%$ up to $40 \%$. The results indicated that the characteristics of wastewater complied with the BS and ASTM standards. In addition, the results also recommended that the concrete mixture with $20 \%$ of wastewater has given the highest compressive strength and modulus of elasticity.
\end{abstract}

\section{Introduction}

Recently, construction industry development board (CIDB) of Malaysia has indicated that the number of projects for building and civil engineering work has been recorded the highest numbers compared to electrical and mechanical sectors [1, 2][37]. This growth is due to the greatest investment in construction development projects under the 10th Malaysia Plan from 2011 to 2015 [3]. In line with that, the water demand in construction industries increased dramatically especially Ready Mixed Concrete because it is one of the main suppliers in housing areas [4, 5][36]. Subsequently, previous researchers estimated that approximately 500 to 1500 litres of tap water is required to clean each concrete mixer truck at the end of each day [6-9]. At the same time, slurry water might be produced after

* Corresponding author: shahiron@uthm.edu.my 
washing the mixer truck which might lead to environmental pollution [10][35]. Previous studies also mentioned that normally the $\mathrm{pH}$ value of slurry water from $\mathrm{pH} 11$ to 12.5 [6-8]. In addition, slurry water is also classified as dangerous wastewater as it can cause surface bodies of water due to alkaline characteristics [4]. Apart from that, typical slurry water that been produced from the ready mixed concrete plants contains dissolved solids such as calcium chloride and sulphate from cement as an admixture [5, 6]. Besides, the investigation on the concrete manufacturing using slurry water from RMC plants also has been conducted [7]. From the studied, it found that the slurry water has a highest content of alkaline and total solids which is exceeded the limit as required in ASTM C94, which may cause the concrete to be more porous and contains a weaker matrix $[8,9]$.

Reusing alternative car wash wastewater in concrete mixes aims to create a sustainable solution in this industry towards green technology in construction materials. Some researched has used car wash wastewater to manufacture concrete which is the wastewater characteristics include $\mathrm{pH}$ value, chloride, alkalinity and sulphate content in wastewater was also determined in this study [11]. The results indicated that the wastewater characteristics were within the ASTM standard limits. The mechanical tests including compressive strength, tensile strength and flexural test were done on day 28 . In addition, the percentages of car wash wastewater in the concrete mix ranged from $25 \%$ to $100 \%$ [11].

Last but not least, there is a lack in literature on the utilization of wastewater in concrete mixing. This research focused mainly on the characteristics of slurry water and car wash wastewater and the effect of the wastewater on concrete properties. Meanwhile, the mechanical tests for concrete were conducted according to ASTM standards as a guidelines, which is also included compressive strength, tensile strength and modulus of elasticity.

\section{Materials and method}

In this research, the percentages of slurry water used in concrete mixes ranged from $10 \%$ to $50 \%$ and $10 \%$ to $40 \%$ for car wash wastewater. The water cement ratio w/c is 0.45 and all the concrete specimens were designed to have a target mean strength of $35 \mathrm{MPa}$ with a slump value between $30 \mathrm{~mm}$ to $60 \mathrm{~mm}$. The concrete mix was designed according to the method set by the Department of Environment (DOE). In addition, the properties of fresh concrete such as unit weight, slump test and the mechanical tests including compressive strength, tensile strength and modulus of elasticity (MOE) were carried out in this study. The concrete specimens tested for compressive strength were cast in moulds with dimensions of $150 \times 150 \times 150 \mathrm{~mm}$ while those tested for tensile strength and MOE were cast in $300 \mathrm{~mm} \times 150 \mathrm{~mm}$ diameter moulds. Triplicate concrete samples were made for each concrete mechanical testing.

\subsection{Materials}

\subsubsection{Wastewater (slurry and carwash)}

Slurry water was collected from three different RMC plants in Batu Pahat, Johor, Malaysia which are Hanson RMC plant, Chin Keng RMC plant and Renggam RMC plant. Before the slurry water was collected, the wash water from concrete mixer truck was discharged into a pit at the RMC plant. On the other hand, car wash wastewater was collected from two different car wash stations in Batu Pahat, Johor, Malaysia which are MJ car wash and Bandar U car wash. Before the wastewater was collected, the washout water from the vehicle was discharged into a pond through a drainage system. The chemical properties of 
wastewater were analyzed according to the USEPA standard method and compared with the standard specifications [11].

\subsubsection{Cement}

A local Ordinary Portland cement type CEM $142.5 \mathrm{~N}$ was used in this study. The cement complied with the requirements of MS EN 197-1.

\subsubsection{Aggregates}

A fine aggregate which is natural sand met the ASTM C33 requirements $[12,13]$. The coarse aggregate consisted of crushed rocks and also complied the ASTM C33 specifications. The fine aggregate passed through a $5 \mathrm{~mm}$ sieve (No 4 ) and were retained at $75 \mu \mathrm{m}$ (no 200). The coarse aggregate passed through a $20 \mathrm{~mm}$ sieve and retained at $10 \mathrm{~mm}$. All the aggregates were air dried at $20+5^{\circ} \mathrm{C}$ to obtain saturated surface dry condition.

\subsection{Mix proportion of concrete}

In this research, all concrete specimens were designed to have a target mean strength of $35 \mathrm{MPa}$ with the curing process of 28 days according to the Department of Environment, DOE method.

\subsection{Experimental work}

\subsubsection{Wastewater analysis}

The $\mathrm{pH}$ value of wastewater was measured by using Hanna HI 8424 digital $\mathrm{pH}$ meter. According to the United States Environmental Protection Agency (USEPA) method 300.0, the content of chloride and sulphate in car wash wastewater were analysed. In addition, all the results of wastewater characteristics were compared with ASTM and BS standards.

\subsubsection{Concrete testing}

The manufacturing and curing process of concrete were according to ASTM standards. However, the concrete slump tests were performed according to ASTM C 143[14].Besides, the tests for unit weight of concrete were conducted according to ASTM C138 [15]. On the other hand, the compressive strength and tensile strength of concrete on day 7 and day 28 were carried out in accordance with ASTM C39 and ASTM C496 respectively [16,17,32]. Meanwhile, the modulus of elasticity of concrete on day 28 was tested according to ASTM C469 [18].

\section{Results and discussion}

\subsection{Design requirement}

Table 1 and Table 2 show the results of the characteristics of wastewater and tolerance limit of water mixed in concrete respectively. Based on Table 1 and Table 2, the slurry water and car wash wastewater characteristics completely complied with the standards as well as the typical values suggested by previous researchers except for the $\mathrm{pH}$ value for car wash wastewater. Even though this study obtained higher $\mathrm{pH}$ values compared to the previous 
studies, the range of $\mathrm{pH}$ values is still in the range of typical car wash wastewater which varies from 6.0 to 9.0 .

Table 1. Characteristic of wastewater.

\begin{tabular}{|c|c|c|c|}
\hline \multirow{2}{*}{$\begin{array}{c}\text { Sources/ } \\
\text { Parameters }\end{array}$} & \multicolumn{3}{|c|}{ Parameters } \\
\cline { 2 - 4 } & $\mathrm{pH}$ & $\begin{array}{c}\text { Chloride } \\
\mathrm{CI}^{-}, \mathrm{ppm}\end{array}$ & $\begin{array}{c}\text { Sulphate } \\
\mathrm{SO}_{4}^{2-}, \mathrm{ppm}\end{array}$ \\
\hline \multicolumn{4}{|c|}{ Slurry water } \\
\hline Hanson & $10.0-11.3$ & $7.5-46.9$ & $108.6-454.9$ \\
\hline Chin Keng & $11.0-11.9$ & $6.7-28.7$ & $426.0-289.5$ \\
\hline Renggam & $11.6-12.1$ & $19.9-33.7$ & $69.4-475.8$ \\
\hline \multicolumn{4}{|c|}{ Carwash Wastewater } \\
\hline MAHAJU (MJ) Car wash & $8-8-9.5$ & $19.4-33.0$ & $12.6-115.5$ \\
\hline Bandar U Carwash & $9.5-10.6$ & $18.2-25.4$ & $16.1-100.4$ \\
\hline \multicolumn{4}{|c|}{ Tap water } \\
\hline Tap water & $7.6-8.1$ & $19.4-19.7$ & $13.3-13.4$ \\
\hline
\end{tabular}

Table 2. Tolerance limit of water in mixed concrete.

\begin{tabular}{|c|c|c|c|}
\hline \multirow{2}{*}{ Standards } & \multicolumn{3}{|c|}{ Tolerance limit, ppm } \\
\cline { 2 - 4 } & $\mathrm{pH}$ & $\begin{array}{c}\text { Chloride } \\
\mathrm{CI}^{-}, \mathrm{ppm}\end{array}$ & $\begin{array}{c}\text { Sulphate } \\
\mathrm{SO}_{4}^{2-}, \mathrm{ppm}\end{array}$ \\
\hline ASTM C1602 & - & $<500$ & $<3000$ \\
\hline ASTM C685 & - & $<500$ & $<3000$ \\
\hline BS EN 1008 & $>4$ & $<500$ & $<2000$ \\
\hline BS 3148 & - & $<5007$ & $<1000$ \\
\hline \multicolumn{4}{|c|}{ Previous Researchers (slurry water) } \\
\hline P5-9] & $8.1-13.5$ & $20.8-355.0$ & $12.7-1152$ \\
\hline Previous Researchers (car wash wastewater) \\
\hline$[13-14][19][31]$ & $6.5-8.75$ & $9-74.2$ & $21.3-188.0$ \\
\hline
\end{tabular}

In addition, the higher $\mathrm{pH}$ value in car wash wastewater may be due to chemicals used in pre-soak stages during the car wash process as supported by previous studies by Zaneti et al., [15]. Furthermore, according to BS EN 1008 mentioned that the typical $\mathrm{pH}$ value of water for mixing concrete was at least more than four $(>4)$. Based on that, wastewater has a higher potential to be used as replacement in concrete mixes due to its reasonable characteristics.

\subsection{Properties of fresh concrete}

\subsubsection{Slump test}

In this study, the concrete slump test was analysed according to ASTM C143 standards and the results were listed in Table 3. From Table 3, the slump values for both types of 
wastewater were comparable to the control mix. As mentioned in sub topic 2, the target mean slump value varies from $30 \mathrm{~mm}$ to $60 \mathrm{~mm}$. These findings definitely proved that the slump value of concrete containing wastewater were in the designated range. In addition, the results show that a higher replacement percentage of wastewater in concrete mix results in greater slump value.

Table 3. Slump Test.

\begin{tabular}{|c|c|c|c|c|c|c|c|c|c|c|}
\hline $\begin{array}{c}\text { Waste- } \\
\text { water } \\
\text { Type }\end{array}$ & $\mathrm{CM}$ & $\begin{array}{c}\text { SW10 } \\
\%\end{array}$ & $\begin{array}{c}\text { SW20 } \\
\%\end{array}$ & $\begin{array}{c}\text { SW30 } \\
\%\end{array}$ & $\begin{array}{c}\text { SW40 } \\
\%\end{array}$ & $\begin{array}{c}\text { SW50 } \\
\%\end{array}$ & $\begin{array}{c}\text { CW10 } \\
\%\end{array}$ & $\begin{array}{c}\text { CW20 } \\
\%\end{array}$ & $\begin{array}{c}\text { CW30 } \\
\%\end{array}$ & $\begin{array}{c}\text { CW40 } \\
\%\end{array}$ \\
\hline $\begin{array}{c}\text { Slump } \\
\text { value } \\
(\mathrm{mm})\end{array}$ & 32 & 43 & 39 & 40 & 42 & 48 & 42 & 38 & 43 & 45 \\
\hline
\end{tabular}

\subsection{Mechanical properties of concrete}

\subsubsection{Compressive strength}

Fig. 1 showed the comparison of compressive strength between slurry water and car wash wastewater mix against the control mix.

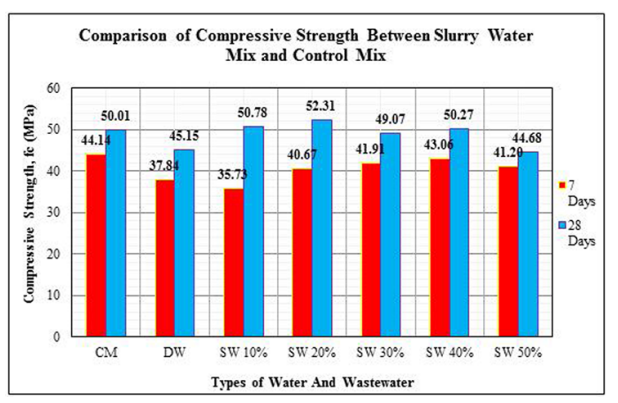

(a)

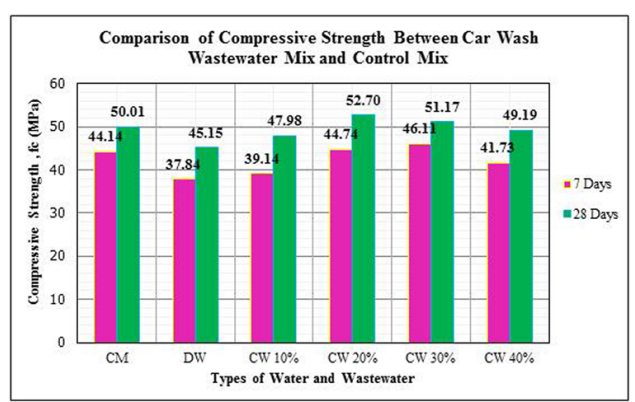

(b)

Fig. 1. Comparison of compressive strength between; (a) slurry water and (b) Car Wash.

According to Fig. 1, all types of slurry water shows the higher strength than the minimum limit of $90 \%$ specified in the standards except for concrete specimen with contain $10 \%$ of slurry water (SW10\%) at only $80.95 \%$. However, on day 28 , the concrete specimen that contains $10 \%$ to $40 \%$ of slurry water has exceeded the limit of the compressive strength, meanwhile by $50 \%$ replacement of slurry water in concrete mix was below the minimum limit. This is because the proportion of water for concrete (SW50\%) consisted of $50 \%$ of slurry water and $50 \%$ of tap water, which would cause the $\mathrm{pH}$ value to become higher than others. This can be seen from Table 1, where the $\mathrm{pH}$ value for slurry water is between 10 to 12.1 compared to tap water which is 7.6 to 8.1 . According to the previous studied, the researchers mentioned that the typical range of $\mathrm{pH}$ value for water used in concrete manufacturing is between 6.0 to $9.0[20,21,22,30]$.

On the other hand, the compressive strength of car wash wastewater concrete was in the range of $88 \%$ to $104 \%$ of normal concrete. This range was beyond the minimum limit of $90 \%$ that was specified in ASTM C1602 except for the $10 \%$ car wash wastewater replacement. However, on day 28 all the specimens of concrete mixed with car wash wastewater not only went above the limits of the standard, but also indicated a slight 
improvement especially for the concrete with $20 \%$ and $30 \%$ car wash wastewater replacement. This finding may be due to the fine solid particles present in the car wash wastewater could fill the pores or voids between fine aggregates and coarse aggregates so that the strength of concrete could be improved but that would depend on suitable replacement percentages of car wash wastewater in concrete mixes as mentioned and supported by these researchers [23, 24, 29].

In addition, the highest compressive strength for concrete with car wash wastewater was approximately $52.7 \mathrm{MPa}$ compared to concrete with slurry water which is $52.3 \mathrm{MPa}$. This may be due to the lower sulphate content in car wash wastewater which is $12.6 \mathrm{ppm}$ to $115.5 \mathrm{ppm}$ compared to slurry water with a range between $42.6 \mathrm{ppm}$ to $475.8 \mathrm{ppm}$. This is because the presence of sulphate content in wastewater may be generated from ash or residue. Thus, the higher sulphate content in wastewater may result in a lot of waste such as ash and residues which may decrease concrete permeability and reduce the strength of the concrete [19].

\subsubsection{Modulus of elasticity (MOE)}

Consequently, Fig. 2 presented the comparison of modulus of elasticity between slurry water and car wash wastewater mix against control mix.

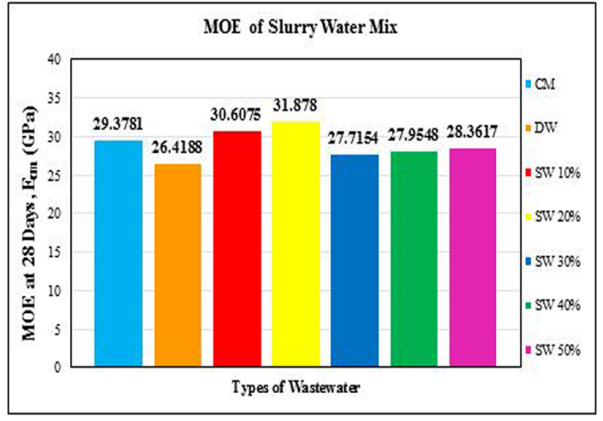

(a)

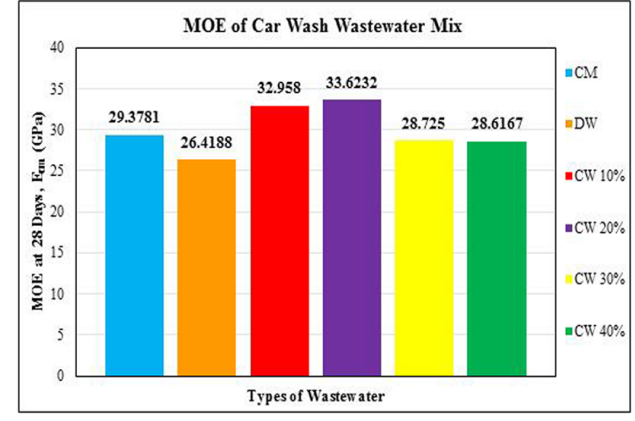

(b)

Fig. 2. MOE of ; (a) Slurry water and (b) Car Wash.

As stated in BS EN 1992, usually the range of modulus of elasticity of concrete (Ecm) for grade 35 is $32+6 \mathrm{GPa}$ [25]. Based on Table 7, the results completely achieved the required range of MOE for concrete with a mean strength of $35 \mathrm{MPa}$. In addition, ACI 31802 and Neville, (1995) also mentioned that the typical MOE value for concrete with a compressive strength of 35 was $30 \mathrm{GPa}$ [26][34]. Therefore, by comparing the data in Table 7 with previous studies, it is clear that the MOE value of slurry water and car wash wastewater complied with the suggested ranges.

On the other hand, the concrete with $20 \%$ car wash wastewater replacement demonstrated the highest MOE value at $33.6 \mathrm{GPa}$ compared to slurry water as well as control mix with only $31.9 \mathrm{GPa}$ and $29.3781 \mathrm{GPa}$ respectively. These findings may correlate to the existence of fine solid particles in wastewater which could fill the porosity and voids in between the fine and coarse aggregates in concrete structures. According to previous researchers, the factors affecting the MOE were concrete strength and concrete density $[27,28]$. The concrete strength was related to the concrete compressive strength while the concrete density was related to the porosity of concrete. Based on the results in Table 1, the sulphate content in car wash wastewater was between $12.6 \mathrm{ppm}$ to $115.5 \mathrm{ppm}$ compared to tap water which was between $13.3 \mathrm{ppm}$ to $13.4 \mathrm{ppm}$. Previous researchers 
revealed that higher sulphate concentration may result in lower concrete impermeability. Thus, it can be summarized that the lower content of sulphate in wastewater may lead to higher MOE of concrete.

\subsubsection{Relationship between compressive strength and MOE}

According to Fig. 1 and Fig. 2, the modulus of elasticity increased when the concrete compressive strength was increased. In addition, the relationship that can be seen has shown that the concrete mixed with $20 \%$ wastewater has achieved the highest compressive strength and modulus of elasticity. Therefore, it can be concluded that the optimum percentage of slurry water and car wash wastewater as a fresh water replacement in concrete mixes is $20 \%$.

\section{Conclusion}

Based on the results from the experimental work, the following conclusions for the use of car wash wastewater in concrete mixes can be drawn: (a) The $\mathrm{pH}$ value for slurry water from ready mixed concrete plants was in the range of 10 to 12 while the $\mathrm{pH}$ value for car wash wastewater was approximately 8.8 to 10.6 . Both types of wastewater had $\mathrm{pH}$ values slightly higher than tap water. However, the content of chloride and sulphate in wastewater were within the ASTM and BS standards requirement; (b) With an increase in the percentage replacement of wastewater in concrete mix has lead to the decrease of compressive strength, and modulus of elasticity of concrete. Generally, the compressive strength of concrete mixed with slurry water is in the range of $81 \%$ to $98 \%$ for the control mix and $88 \%$ to $104 \%$ for concrete mixed with car wash wastewater; (c) According to the results for compressive strength and modulus of elasticity, the optimum percentage of car wash wastewater as a fresh water replacement in concrete mixes is $20 \%$.

The authors would like to express their deepest appreciation to the Ministry of Higher Education Malaysia, Universiti Tun Hussein Onn Malaysia for funding the research under grant U523.

\section{References}

[1] Z.B. Zaharaton, Water resources management in Malaysia - the way forward, Asian Water, Kuala Lumpur, Malaysia, (2004)

[2] S. Shahidan, R. Pullin, K.M. Holford, M.B.N, and N. Nor, Quantitative evaluation of the relationship between tensile crack and shear movement in concrete beams, Advanced Material Research, 626, 355-359, (2013)

[3] CIDB, Construction Statistics Quarterly Bulletin, Construction Industry Development Board Malaysia (CIDB), (Jun 2015)

[4] S. Tsimas and M. Zervaki, Reuse of wastewater from ready-mixed concrete plants. Management of Environmental Quality: An Int. J., 22(1), 7-17, (2011)

[5] A.M. Wahid and H. Tanaka, Potential implementation of wastewater reclamation and reuse in Malaysian urban area, Int. Sustainability and Civil Engineering J., 1(1), 75-83, (2012)

[6] G. Asadollahfardi, M. Delnavaz, V. Rashnoiee, and N. Ghonabadi, Use of treated domestic wastewater before chlorination to produce and cure concrete, Construction Build. Materials, 105, 253-261, (2016)

[7] B. Chatveera, P. Lertwattanaruk and N. Makul, Effect of sludge water from readymixed concrete plant on properties and durability of concrete, Cement and Concrete Composites, 28(5), 441-450, (2006) 
[8] S.A. Kudus, N.M. Bunnori, S.R. Basri, S. Shahidan, M.N.M. Jamil and N.M. Noor, An overview current application of artificial neural network in concrete, Advanced Material Research, 626, 372-375, (2012)

[9] S.A. Chini and W.J. Mbwambo, environmentally friendly solution for the disposal of concrete wash water from ready mixed concrete operations, in Proc. of CIB W89 Beijing Int. Conf., (1996)

[10]R.A. Khan, M.S. Liew and Z. Ghazali, Malaysian construction sector and Malaysia Vision 2020: Developed nation status, Social and Behavioral Sciences, 109, 507-513, (2014)

[11]ASTM C33, Specification for concrete aggregates, Pennsylvania, United States: American Society for Testing and Materials, (2003)

[12]BS 882, Specification for aggregates from natural sources for concrete, London: British Standards Institution, (1992).

[13]BS EN 1008, Mixing water for concrete-specification for sampling, testing and assessing the suitability of water, including water recovered from processes in the concrete industry, as mixing water in concrete, London: British Standards Institution (2002)

[14]ASTM C143, Test method for slump of hydraulic cement concrete, Pennsylvania, United States: American Society for Testing and Materials, (2005)

[15] ASTM C138, Test method for density unit weight, yield and air content of concrete, Pennsylvania, United States: American Society for Testing and Materials, (2005)

[16] ASTM C469, Test method for static modulus of elasticity and poisson ratio of concrete in compression, Pennsylvania, United States: American Society for Testing and Materials, (2002)

[17]ASTM C39, Test method for compressive strength of cylindrical concrete specimens, Pennsylvania, United States: American Society for Testing and Materials, (2005)

[18]ASTM C496, Test method for splitting tensile strength of cylindrical concrete specimens, Pennsylvania, United States: American Society for Testing and Materials, (2004)

[19] C. Brown, Water conservation in the professional car wash industry, International Car Wash Association, Washington, (2000).

[20]C. Brown, Water use in the professional car wash industry, International Car Wash Association, Washington, (2002)

[21]K.S. Al-Jabri, A.H. Al-Saidy, R. Taha and A.J. Al-Kemyani, Effect of using wastewater on the properties of high strength concrete, Procedia Engineering, 14, 370$376,(2011)$

[22]K.J. Kucche, quality of water for making concrete: A review of literature, J. of Scientific and Research Publications, 5(1), 201-205, (2015)

[23]K.S. Al-Jabri, A.H. Al-Saidy, R. Taha and A.J. Al-Kemyani, Effect of using wastewater on the properties of high strength concrete, Procedia Engineering, 14, 370376,( 2011)

[24]R. Zaneti, R. Etchepare and J. Rubio, Car wash wastewater reclamation. Full- scale application and upcoming features, Resources, Conservation and Recycling, 55(11), 953-959, (2011)

[25]K.P. Mehta and P.J. Monteiro, Concrete: Microstructure, Properties, and Materials, $4^{\text {th }}$ ed., New York: Mc Graw Hill, (2014)

[26]BS EN 1992, Design of concrete structure, London: British Standards Institution, (2004)

[27] A.M. Neville, Properties of concrete, Concrete Technology, 4th ed., London: Pearson, (1995) 
[28]M.A. Rahim, Z. Ghazaly, R. Nurazira, R. Mamat, M.A. Azizan, N.F. Isa, and S. Shahidan, Experimental study of slurry infiltrated fiber reinforced concrete, Material Science Forum, 857, 363-366, (2016)

[29] M. Abdul Rahim, N.M. Ibrahim, Z. Idris, Z.M. Ghazaly, S. Shahidan, N.L. Rahim, L. A. Sofri, and N. F. Isa, Properties of concrete with different percentange of the rice husk ash (RHA) as partial cement replacement, Material Science Forum, 803, 288293, (2014)

[30] S. Shahidan, N.M. Bunnori, N. Md Nor and S.R. Basri, Damage severity evaluation on reinforced concrete beam by means of acoustic emission signal and intensity analysis, IEEE Symposium on Industrial Electronics and Applications, 337-341, (2011)

[31]S. Shahidan, I. Isham and N. Jamaluddin, A Review on waste minimization by adopting in self compacting concrete, MATEC Web Conf., 47, 1-7, (2016)

[32] J.M. Irwan, S.K. Faisal, N. Othman, M.H. Wan Ibrahim, R.M. Asyraf, M.M.K. Annas, Performance of concrete using light waste PET fibre, Advanced Materials Research, 795, 352-355, (2014)

[33]R.P. Jaya, B.H. Abu Bakar, M.A.M. Johari, M.H.W. Ibrahim, M.R. Hainin and D.S. Jayanti, Strength and microstructure analysis of concrete containing rice husk ash under seawater attack by wetting and drying cycles, Advances in Cement Research., 26(3), 145-154, (2014)

[34] S. Shahidan, M.S. Senin, A.A. Kadir, L.H. Yee and N. Ali, properties of concrete mixes with carwash wastewater, MATEC Web Conf., 87(1018), 1-6, (2017)

[35] S. Shahidan, S.S. M. Zuki and N. Jamaluddin, Damage grading system for severity assessment on concrete structure, Case Stud. Constr. Mater., 5,79-86, (2016)

[36] S. Shahidan, I. Isham and N. Jamaluddin, A review on waste minimization by adopting in self compacting concrete, MATEC Web Conf., 47, 1-7, (2016)

[37] S. Shahidan, S.S. Mohd Zuki, M.A. Rahim and N. Ali, Amplitude distribution of emission wave for cracking process, MATEC Web Conf., 47, 2-8, (2016) 